\title{
An Analysis of Requirements on Government Economic Behaviors from Social Structural Transformation under The New Normal
}

\author{
Yike Yang ${ }^{1, a}$ \\ ${ }^{1}$ North China Electric Power University, Beijing 102206 , China \\ aechoyang@foxmail.com
}

\begin{abstract}
Keywords: New Normal; Social Structural Transformation; Government economic behavior; Requirement

Abstract. Under the background of new normal, great changes have taken place in China' s market economic system, which push further forward social structural transformation and development from traditional society to modern society, and brought all-round impacts on development of modern society. Especially, new requirements of government economic behaviors are brought forward to further clarify the problems in government economic behaviors during the development process and optimize government economic behaviors under the social structural transformation, This paper gives an analysis on the requirements of government economic behaviors from social structural transformation under the background of the new normal.
\end{abstract}

\section{Introduction}

Social structural transformation refers to the transition from traditional

planned economy system to the modern market economy system and the traditional centralized political system from modern democratic system with the transition from humanist direction to the direction of science and culture. Thus it can be seen that, social structural transformation not only influences development of China's economic construction but also stability of our national political system. In today's China, there are offside and misconduct of duty in political and economic behaviors that seriously affect the important status of Chinese government in social development and need to be improved from the perspective of social structural transformation.

\section{Problems in Government Economic Behaviors}

Human has developed distinctive behavior characteristics during development that are mainly influenced by external factors. Under different stimuli of the external environment, human makes different reactions and exhibit different behavior characteristics. The specific behavior process is as shown in Fig. 1-1:

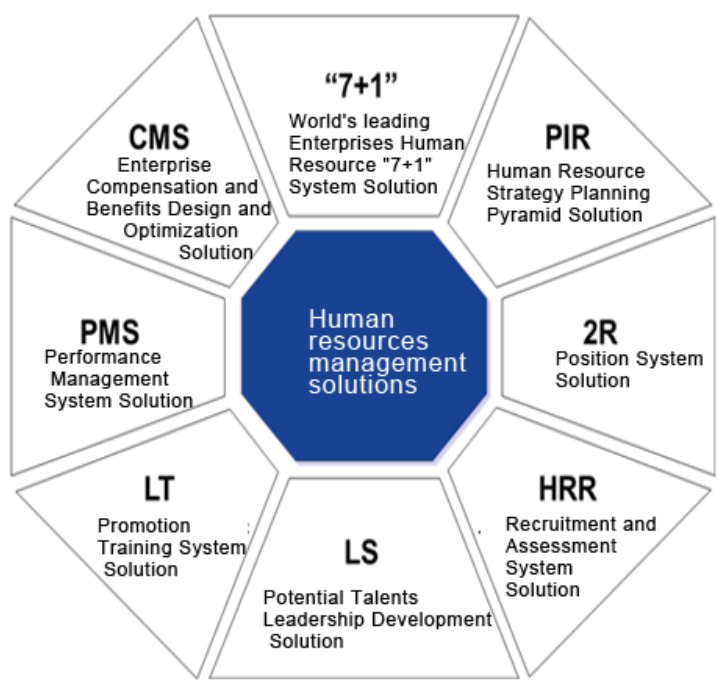

Fig. 1-1 Human Behavior Process 
Government economic behaviors are on the basis of behaviors during development, and its entire development also complies with the such process as shown in Fig. 1.2.

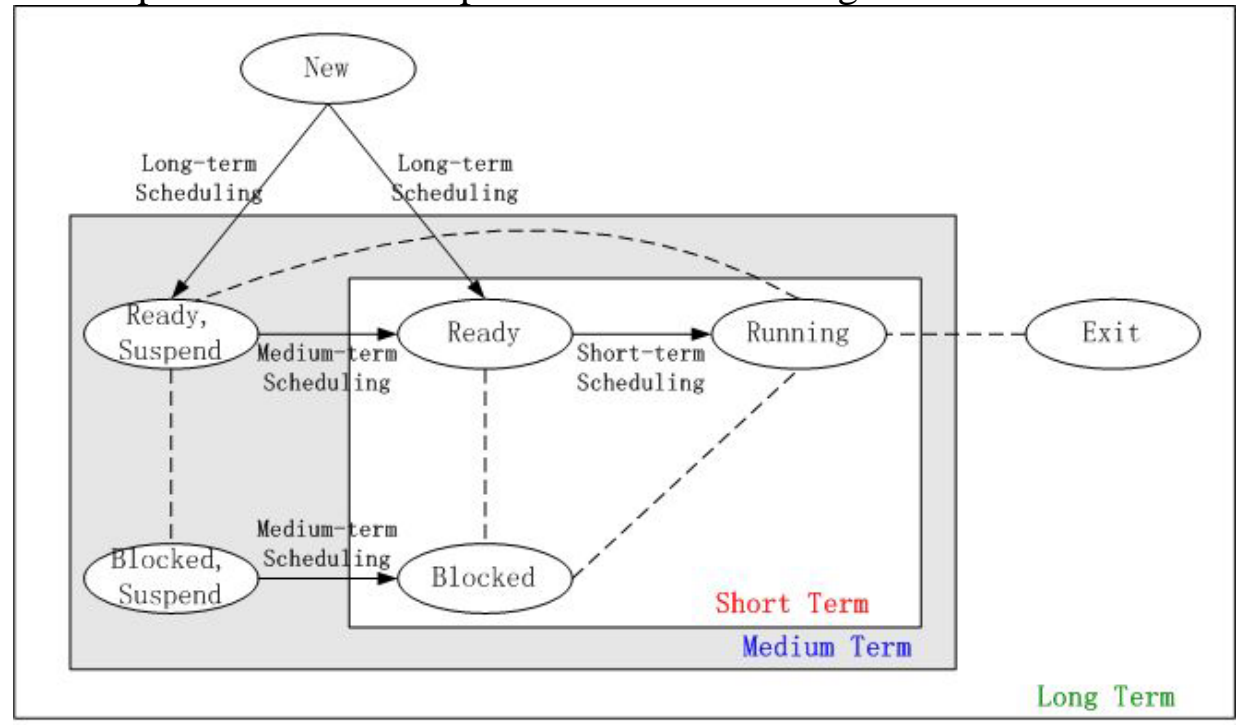

Fig. 1-2 Process of Government Economic Behavior

As the subject of economic behaviors, government economic behaviors shall be based on relevant laws and regulations that provides explicit regulations to maximize the important role of government economic function in social development. However, in today's China, there are offside and misconduct of duty during development of government economic behaviors.

(I) Offside of duty in government economic behaviors

Offside of duty in government economic behaviors refers to the redundant intervention given to the market even taking the place of market in carrying out economic activities by the government in the process of exercising its economic rights, which intensifies,the restriction of the principal status of market economy system to some extent, causes the situation where the government contends for profits with the main market player, and hinders development of market economy system. Through interview and investigation by the author, it is found that, at the present stage, offside of duty in the economic behaviors of Chinese government is mainly reflected in three aspects, as shown in Table 1-1:

Table 1-1 Main Manifestations of Offside of Duty in Government Economic Behaviors

\begin{tabular}{ll}
\hline Item & Percentage \\
\hline Direct investment from the government in & $29 \%$ \\
economical fields & \\
Direct investment promotion as the market & $37 \%$ \\
main player by the right of allocation of & \\
resources endowed with & \\
Economic activity carried out to gain & $34 \%$ \\
profits by the government taking advantage of & \\
its functions
\end{tabular}

From the above Table we can see that, at present, the offside of duty in the economic behaviors of Chinese government is quite severe, too much involvement in resource allocation and monopoly of market resources of the government impede development of market economy system to a certain degree, and dramatically reduce results of resource allocation. Consequently, the fundamental principles of fairness, impartiality and openness for development of market economy are violated, crowding-out effect of investment from social resources are produced, which jointly further lower the aggregate investment level of social capital and easily lead to power-for-money deal and corruption[2]. 
(II) Misconduct of duty in government economic behaviors

Misconduct of duty in government economic behaviors refers to the evolvement of the economic rights of the government exercised for the purpose of social public interests into the tools deviating from the essence of the rights, which are manipulated by the individuals and departments seeking personal gains. The departmentalization, localization and individualization of public rights severely affect regular development of government economic behaviors. Misconduct of duty in government economic behaviors is mainly reflected in four aspects, as shown in Table 1-2:

Table 1-2 Main Manifestations of Misconduct of Duty in Government Economic Behaviors

\begin{tabular}{|l|l|}
\hline Item & \multicolumn{1}{|c|}{ Manifestation } \\
\hline Local protectionism & $\begin{array}{l}\text { Some local governments implement } \\
\text { market blockade by all means in the hope } \\
\text { of maximizing the economic benefits, and } \\
\text { impose restrictions on exchanges between } \\
\text { the local and external market in virtue of } \\
\text { local protectionism, which easily lead the } \\
\text { problems of tax evasion and forged and } \\
\text { fake commodity of local enterprises }\end{array}$ \\
\hline Departmental protectionism & $\begin{array}{l}\text { Government department abuses its } \\
\text { basic functions to seek personal interests } \\
\text { with the economic rights and turn a blind } \\
\text { eye to price alliance, price discrimination } \\
\text { and redundant charge and so on. }\end{array}$ \\
\hline Dysfunctional supervision & $\begin{array}{l}\text { The government fails to establish strict } \\
\text { market regulation standards, but imposes } \\
\text { too much limitations on development of } \\
\text { market economy, which reduces vitality } \\
\text { of market competition to a certain degree, } \\
\text { and neglects supervision of food and drug } \\
\text { safety, which is much more serious in the } \\
\text { practical situation. }\end{array}$ \\
\hline $\begin{array}{l}\text { Under limitations imposed by the } \\
\text { government, regulators fail to conduct } \\
\text { analysis from the perspective of public } \\
\text { interests but seek profits for a small group } \\
\text { of people, that is to say, they are } \\
\text { "captured” by politics and promote private } \\
\text { interests using functions and powers of the } \\
\text { government. }\end{array}$ \\
\hline Regulators being "captured”
\end{tabular}

If the misconduct of duty in government economic behaviors cannot be corrected, the market economy would be carved up by various government departments, which will not only hinder stable development of China's market economy construction, reduces China's market competitiveness but also harm the legal rights and interests of consumers[3].

\section{Requirements on Government Economic Behaviors from Social Structural Transformation under the Background of New Normal}

(I) Government economic behaviors shall be rigorously standardized

During the development process, government economic behaviors shall be based on relevant laws and regulations, especially under constant transformation of social structure, legalization and institutionalization of government economic behaviors shall be strengthened. Meanwhile, rigorous national administrative norms shall be established to ensure government economic behaviors are in line with the programs and resolutions of the CPC so as to further enhance moral constraint on 
government economic behaviors and make sure implementation of the behaviors comply with the standards in social morals, professional ethics and civic virtues[4].

(II) Government economic behaviors shall be moderate

Government economic behaviors can supplement the deficient market behaviors, actively modify market economic behaviors and effectively solve failure of market economic behaviors, but the government should better not involve in the problems that the market can solve by itself. Therefore, under the background of the new normal, moderate government economic behaviors are mainly reflected in moderate range and operating force so as to further regularize government economic behaviors.

(III) Government economic behaviors shall be clean-fingered

At the present, Chinese leaders are targeting on tackling of corruption by taking a strong stance against corruption of government officials, building correct service awareness and vocational qualities, and carrying out government economic behaviors on the basis of integrity to avert the influence of corruption on healthy development of China's market economy and make contribution to the great rejuvenation of Chinese nation. In addition, clean-fingered government economic behaviors can dramatically reduce political disorder and push further forward sustainable development of China's modern economy system[5].

\section{Conclusion}

Based on the above analysis, with the constant progress of the times, social and economic transformation have become the inexorable trend of development of modern society and put forward new requirements on development of China's economic behaviors. Therefore, it is necessary to standardize from the perspective of the law and morality and exert strict limitations on government economic behaviors to avoid excessive intervention in market economy system, corruption of government officials and push forward sustainable progress of social development and state construction.

\section{References}

[1]Duarte M, Restuccia D. THE ROLE OF THE STRUCTURAL TRANSFORMATION IN AGGREGATE PRODUCTIVITY[J]. Quarterly Journal of Economics, 2006, 125(1):129-173.

[2]Rogerson R. Structural Transformation and the Deterioration of European Labor Market Outcomes[J]. Journal of Political Economy, 2008, 116(Volume 116, Number 2):235-259.

[3]Cheong $\mathrm{T} \mathrm{S}, \mathrm{Wu} \mathrm{Y}$. The impacts of structural transformation and industrial upgrading on regional inequality in China[J]. China Economic Review, 2014, 31(C):339-350.

[4]Hilber C A L. New housing supply and the dilution of social capital[J]. Journal of Urban Economics, 2010, 67(3):419-437.

[5]Yeung W C. Multinational Corporations in China: Benefitting from Structural Transformation[J]. Asia Pacific Journal of Management, 2001, 18(1):113-116. 